\title{
MAKALAH
}

\section{Guru sebagai jabatan fungsional}

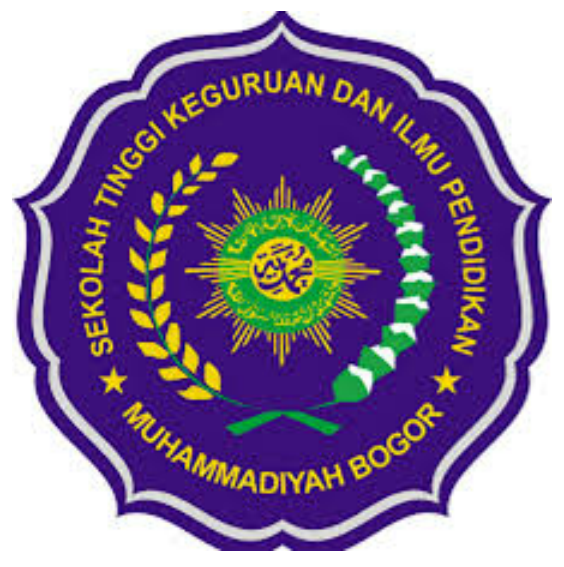

DOSEN PEMBIMBING :

Wahyu Bagja Sulfemi, M. Pd.

Disusun oleh:

Sukma Febritya Dracena

0142S1A018048 


\section{Abstrak:}

Jabatan fungsional guru adalah jabatan fungsional yang mempunyai ruang lingkup, tugas, tanggung jawab, dan wewenang untuk melakukan kegiatan mendidik, mengajar, membimbing, mengarahkan, melatih, menilai, dan mengevaluasi peserta didik pada anak usia dinijalur pendidikan formal, pendidikan dasar, dan pendidikan menengah sesuai dengan peraturan perundang- undangan yang diduduki oleh Pegawai Negeri Sipil.

Dalam Pasal 1 UU No 14 tahun 2005 tentang Guru dan Dosen (selanjutnya disingkat UUGD) disebutkan bahwa Guru adalah pendidik profesional dengan tugas utama mendidik, mengajar, membimbing, mengarahkan, melatih, menilai, dan mengevaluasi peserta didik pada pendidikan anak usia dini jalur pendidikan formal, pendidikan dasar, dan pendidikan menengah. (Sulfemi, 2016: 141)

Tugas guru meliputi mendidik, mengajar, membimbing, mengarahkan, melatih, menilai, dan mengevaluasi peserta didik. 


\section{Guru sebagai jabatan fungsional}

\section{A. Pengertian}

Jabatan fungsional adalah kedudukan yang menunjukkan tugas, tanggung jawab, wewenang dan hak seorang Pegawai Negeri Sipil dalam suatu satuan organisasi yang dalam pelaksanaan tugasnya didasarkan pada keahlian dan keteranpilan tertentu serta bersifat mandiri.

Jabatan fungsional guru adalah jabatan fungsional yang mempunyai ruang lingkup, tugas, tanggung jawab, dan wewenang untuk melakukan kegiatan mendidik, mengajar, membimbing, mengarahkan, melatih, menilai, dan mengevaluasi peserta didik pada anak usia dinijalur pendidikan formal, pendidikan dasar, dan pendidikan menengah sesuai dengan peraturan perundang- undangan yang diduduki oleh Pegawai Negeri Sipil.

Dalam Pasal 1 UU No 14 tahun 2005 tentang Guru dan Dosen (selanjutnya disingkat UUGD) disebutkan bahwa Guru adalah pendidik profesional dengan tugas utama mendidik, mengajar, membimbing, mengarahkan, melatih, menilai, dan mengevaluasi peserta didik pada pendidikan anak usia dini jalur pendidikan formal, pendidikan dasar, dan pendidikan menengah. (Sulfemi, 2016: 141)

Guru adalah tenaga profesional dituntut menjadi manusia yang berdedikasi tinggi, loyal, berkemauan keras, memiliki etos kerja yang tinggi, bermotivasi tinggi dan berdisiplin yang dapat mendukung berhasilnya visi dan misi suatu sekolah sebagai organisasi. Untuk menuju keberhasilan pendidikan terutama adalah menghasilkan peserta didik yang menjadi manusia unggul dalam ilmu pengetahuan, akhlak dan kemanusiaan bukan pribadi yang lemah, KKN, tidak bertanggung jawab, tidak bersosial dan tidak mandiri (Sulfemi, 2016: 343)

\section{B. Tugas Guru}

- Mendidik

Dari segi isi, mendidik sangat berkaitan dengan moral dan kepribadian. Jika ditinjau dari segi proses, maka mendidik berkaitan dengan memberikan motivasi untuk belajar dan mengikuti ketentuan atau tata tertib yang telah menjadi kesepakatan bersama. Kemudian bila ditilik dari segi strategi dan metode yang digunakan, mendidik lebih menggunakan keteladan dan pembiasaan. 
- Mengajar

Jika ditinjau dari segi isi, maka mengajar berupa bahan ajar dalam bentuk ilmu pengetahuan. Prosesnya dilakukan dengan memberikan contoh kepada siswa atau mempraktikkan keterampilan tertentu atau menerapkan konsep yang diberikan kepada siswa agar menjadi kecakapan yang dapat digunakan dalam kehidupan sehari-hari. Strategi dan metode yang dapat digunakan untuk mengajar misalnya ekspositori dan inkuiri.

- Membimbing

Ditinjau dari segi isi, maka membimbing berkaitan dengan norma dan tata tertib. Dilihat dari segi prosesnya, maka mendidik dapat dilakukan dengan menyampaikan atau mentransfer bahan ajar yang berupa ilmu pengetahuan, teknologi dan seni dengan menggunakan strategi dan metode mengajar yang sesuai dengan perbedaan individual masing-masing siswa. Lalu kalau dilihat dari strategi dan metode yang digunakan, maka membimbing lebih berupa pemberian motivasi dan pembinaan.

- Mengarahkan

Mengarahkan memiliki arti suatu kegiatan yang dilakukan oleh guru kepada peserta didik agar dapat mengikuti apa yang kita perintahkan sesuai dengan tujuan yang akan dicapai.

- Melatih

Melatih bila ditinjau dari segi isi adalah berupa keterampilan atau kecakapan hidup (life skills). Bila ditinjau dari prosesnya, maka melatih dilakukan dengan menjadi contoh (role model) dan teladan dalam hal moral dan kepribadian. Sedangkan bila ditinjau dari strategi dan metode yang dapat digunakan, yaitu melalui praktik kerja, simulasi, dan magang.

- Menilai

Kegiatan yang dilakukan oleh guru untuk memperoleh informasi untuk dijadikan sebagai pengambil keputusan tentang hasil belajar peserta didik.

- Mengevaluasi

Pemberian nilai terhadap kualitas sesuatu. Seorang guru setelah menilai siswa nya kemudian mengevaluasinya dengan memberikan nilai.

Tingkat keerhasilan guru dalam menyelesaikan pekerjaannya disebut dengan istilah 
"level of performance" atau level kinerja, guru yang memiliki kinerja tinggi merupakan guru yang memiliki produktivitas kerja sama dengan atau diatas standar yang ditentukan,begitupun sebaliknya guru yang memiliki level kinerja rendah maka guru tersebut merupakan guru yang tidak produktif (Sulfemi, 2018: 97)

\section{Hak, Kewajiban, Tanggung Jawab, dan Kewenangan Guru}

\section{Undang-Undang No. 14 Tahun 2005 Tentang Guru dan Dosen}

Undang undang ini memuat 84 Pasal yang mengatur tentang ketentuan umum (istilah-istilah dalam undang-undang ini), kedudukan fungsi dan tujuan, prinsip profesionalitas, seluruh peraturan tentang guru dan dosen dari kualifikasi akademik, hak dan kewajiban sampai organisasi profesi dan kode etik, sanksi bagi guru dan dosen yang tidak menjalankan kewajiban sebagaimana mestinya, ketentuan peralihan dan ketentuan penutup. (Sulfemi, 2016: 33)

Adapun hak dan kewajiban Guru telah diatur dalam Undang-Undang nomor 14 tahun 2005, yaitu:

Pasal 14

(1) Dalam melaksanakan tugas keprofesionalan, guru berhak :

a. memperoleh penghasilan di atas kebutuhan hidup minimum dan jaminan kesejahteraan sosial;

b. mendapatkan promosi dan penghargaan sesuai dengan tugas dan prestasi kerja;

c. memperoleh perlindungan dalam melaksanakan tugas dan hak atas kekayaan intelektual;

d. memperoleh kesempatan untuk meningkatkan kompetensi;

e. memperoleh dan memanfaatkan sarana dan prasarana pembelajaran untuk menunjang kelancaran tugas keprofesionalan;

f.memiliki kebebasan dalam memberikan penilaian dan ikut menentukan kelulusan,penghargaan, dan/atau sanksi kepada peserta didik sesuai dengan kaidah 
pendidikan, kode etik guru, dan peraturan perundang-undangan;

g. memperoleh rasa aman dan jaminan keselamatan dalam melaksanakan tugas;

h. memiliki kebebasan untuk berserikat dalam organisasi profesi;

i. memiliki kesempatan untuk berperan dalam penentuan kebijakan pendidikan;

j. memperoleh kesempatan untuk mengembangkan dan meningkatkan kualifikasi akademik dan kompetensi; dan/atau

k. memperoleh pelatihan dan pengembangan profesi dalam bidangnya.

\section{Pasal 20}

Dalam melaksanakan tugas keprofesionalan, guru berkewajiban :

a. merencanakan pembelajaran, melaksanakan proses pembelajaran yang bermutu, serta menilai dan mengevaluasi hasil pembelajaran;

b. meningkatkan dan mengembangkan kualifikasi akademik dan kompetensi secara berkelanjutan sejalan dengan perkembangan ilmu pengetahuan, teknologi, dan seni;

c. bertindak objektif dan tidak diskriminatif atas dasar pertimbangan jenis kelamin, agama, suku, ras, dan kondisi fisik tertentu, atau latar belakang keluarga, dan status sosial ekonomi peserta didik dalam pembelajaran;

d. menjunjung tinggi peraturan perundang-undangan, hukum, dan kode etik guru, serta nilai-nilai agama dan estetika; dan

e. memelihara dan memupuk persatuan dan kesatuan bangsa

Tanggung jawab

Guru bertanggung jawab menyelesaikan tugas utama dan kewajiban sebagai pendidik sesuai dengan yang dibebankan kepadanya.

Kewenangan

Guru berwenang memilih dan menentukan materi, strategi, metode, media 
pembelajaran/bimbingan dan alat penilaian/evaluasi dalam melaksanakan proses pembelajaran/bimbingan untuk mencapai hasil pendidikan yang bermutu sesuai dengan kode etik profesi guru.

\section{Jenis Guru}

Berdasarkan sifat, tugas, dan kegiatan nya, guru digolongkan dalam 3 jenis sebagai berikut:

1. Guru kelas adalah guru yang mempunyai tugas, tanggung jawab, wewenang, dan hak secara penuh dalam proses pembelajaran seluruh mata pelajaran di kelas tertentu di TK/TKLB dan SD/SDLB dan satuan pendidikan formal yang sederajat.

2. Guru mata pelajaran adalah guru yang mempunyai tugas, tanggung jawab, wewenang dan hak secara penuh dalam proses pembelajaran pada 1 mata pelajaran tertentu pada satuan pendidikan formal.

3. Guru bimbingan dan konseling/konselor adalah guru yang mempunyai tugas, tanggung jawab, wewenang, dan hak secara penuh dalam kegiatan bimbingan dan konseling terhadap sejumlah peserta didik satuan pendidikan formal.

\section{E. Jam kerja}

Peraturan Pemerintah Nomor 74 tentang Guru Pasal 52 ayat (2) menyatakan bahwa beban kerja guru paling sedikit memenuhi 24 (dua puluh empat) jam tatap muka dan paling banyak 40 (empat puluh) jam tatap muka dalam 1 (satu) minggu pada satu atau lebih satuan pendidikan yang memiliki izin pendirian dari Pemerintah atau Pemerintah Daerah. Alokasi waktu tatap muka pada tiap jenjang pendidikan berbeda, pada jenjang TK satu jam tatap muka dilaksanakan selama 30 menit, pada jenjang SD 35 menit, pada jenjang SMP 40 menit, sedangkan pada jenjang SMA dan SMK selama 45 menit. Beban kerja guru untuk melaksanakan kegiatan tatap muka tersebut merupakan bagian dari jam kerja sebagai pegawai yang secara keseluruhan paling sedikit 37,5 (tiga puluh tujuh koma lima) jam kerja (@60 menit) dalam 1 (satu) minggu.

Lebih lanjut Pasal 52 ayat (3) menyatakan bahwa pemenuhan beban kerja tersebut dilaksanakan dengan ketentuan paling sedikit 6 (enam)jam tatap muka dalam 1 (satu) minggu pada satu satuan pendidikan tempat tugasnya sebagai guru tetap. 


\section{Soal}

\section{A. Pilihan Ganda}

1. Undang-undang yang mengatur perihal guru dan dosen adalah..

A. UU nomor 14 tahun 2005

B. UU nomor 15 tahun 2005

C. UU nomor 16 tahun 2005

D. UU nomor 43 tahun 1993

2. Menurut Undang-undang nomor 14 tahun 2005 pengertian "Guru adalah pendidik profesional dengan tugas utama mendidik, mengajar, membimbing, mengarahkan, melatih, menilai, dan mengevaluasi peserta didik pada pendidikan anak usia dini jalur pendidikan formal, pendidikan dasar, dan pendidikan menengah". Terdapat dalam pasal berapakah bunyi tersebut?
A. Pasal 8
B. Pasal 3
C. Pasal 4
D. Pasal 1

3. Yang merupakan hak seorang guru adalah sebagai berikut..
A. memperoleh penghasilan di atas kebutuhan hidup minimum dan jaminan kesejahteraan sosial;
B. mendapatkan promosi dan penghargaan sesuai dengan tugas dan prestasi kerja;
C. memperoleh perlindungan dalam melaksanakan tugas dan hak atas kekayaan intelektual
D. Jawaban A, B, C benar 
4. Yang merupakan kewenangan seorang guru adalah...
A. Memilih dan menentukan materi dan strategi
B. Menghukum dengan kekerasan siswanya
C. Tidak mengajar di kelas
D. Tidak melakukan evaluasi terhadap peserta didik

5. Berapa minimal jam kerja seorang Guru selama 1 minggu menurut Peraturan Pemerintah?
A. 24 jam
B. $40 \mathrm{jam}$
C. 30 jam
D. 28 jam

6. Berapa maksimal jam kerja seorang Guru selama 1 minggu menurut Peraturan Pemerintah?
A. 24 jam
B. 40 jam
C. 42 jam
D. 28 jam

7. Kewajiban seorang Guru menurut Undang-undang nomor 14 tahun 2005 pasal 20 adalah sebagai berikut..

A. merencanakan pembelajaran, melaksanakan proses pembelajaran yang bermutu, serta menilai dan mengevaluasi hasil pembelajaran;

B. meningkatkan dan mengembangkan kualifikasi akademik dan kompetensi secara berkelanjutan sejalan dengan perkembangan ilmu pengetahuan, teknologi, dan seni; 
C. bertindak objektif dan tidak diskriminatif atas dasar pertimbangan jenis kelamin, agama, suku, ras, dan kondisi fisik tertentu, atau latar belakang keluarga, dan status sosial ekonomi peserta didik dalam pembelajaran;

D. Jawaban a, b, dan c benar

8. Dalam undang-undang nomor 14 tahun 2005 berisi apa saja yang menjadi hak seorang Guru, terdapat dalam pasal..
A. Pasal 14
B. Pasal 20
C. Pasal 1
D. Pasal 2

9. ... memiliki arti suatu kegiatan yang dilakukan oleh guru kepada peserta didik agar dapat mengikuti apa yang kita perintahkan sesuai dengan tujuan yang akan dicapai. Merupakan pengertian dari..
A. Menilai
B. Mengajar
C. Megarahkan
D. Mendidik

10. Pemberian nilai terhadap kualitas sesuatu. Merupakan pengertian dari..
A. Mengevaluasi
B. Menilai
C. Mendidik
D. Mengajar 


\section{B. Isian}

1. Apa yang dimaksud dengan Guru menurut Undang-undang nomor 14 tahun 2005 ?

2. Apa yang dimaksud dengan jabatan fungsional?

3. Mengapa Guru disebut sebagai jabatan fungsional?

4. Bagaimana peran Guru terhadap perkembangan moral peserta didik nya?

5. Sebutkan tugas Guru menurut undang-undang nomor 14 tahun 2005 ! 


\section{Kunci Jawaban}

\section{A. Pilihan Ganda}

1. A

2. D

3. D

4. A

5. A

6. B

7. D

8. A

9. C

10. A

\section{B. Isian}

1. Guru adalah pendidik profesional dengan tugas utama mendidik, mengajar, membimbing, mengarahkan, melatih, menilai, dan mengevaluasi peserta didik pada pendidikan anak usia dini jalur pendidikan formal, pendidikan dasar, dan pendidikan menengah.

2. Jabatan fungsional adalah kedudukan yang menunjukkan tugas, tanggung jawab, wewenang dan hak seorang Pegawai Negeri Sipil dalam suatu satuan organisasi yang dalam pelaksanaan tugasnya didasarkan pada keahlian dan keteranpilan tertentu serta bersifat mandiri.

3. Karena Guru mempunyai ruang lingkup, tugas, tanggung jawab, dan wewenang untuk melakukan kegiatan mendidik, mengajar, membimbing, mengarahkan, melatih, menilai, dan mengevaluasi peserta didik pada anak usia dinijalur pendidikan formal, pendidikan dasar, dan pendidikan menengah sesuai dengan peraturan perundang- undangan yang diduduki oleh Pegawai Negeri Sipil. 
4. Guru memiliki tugas mendidik muridnya. Sehingga sangat memiliki peran terhadap perkembangan moral peserta didik.

5. Tugas Guru menurut undang-undang nomor 14 tahun 2005 :

Mendidik, mengajar, membimbing, mengarahkan, melatih, menilai dan mengevaluasi. 


\section{Daftar Pustaka}

Pemerintah Indonesia. 2005. Undang-undang nomor 14 tahun 2005 Yang Mengatur Tentang Guru dan Dosen. Lembaran Negara RI Tahun 2005 Nomor 157. Sekretariat Negara. Jakarta.

Teachin.id. 2019. Jenis Jabatan Fungsional Guru dan Tips Naik Pangkat untuk Pendidik. Https://teachin.id/landing/jabatan_fungsional_guru_detail.php (diakses tanggal 13 Oktober 2019)

Maxmanroe. 2019. Pengertian Guru: Definisi, Tugas, dan Peran Guru dalam Pendidikan. Https://www.maxmanroe.com/vid/umum/pengertian-guru.html (diakses tanggal 14 Oktober 2019)

Sulfemi, Wahyu Bagja. (2016). (Perundang-Undangan Pendidikan. Bogor : Program Studi Administrasi Pendidikan STKIP Muhammadiyah Bogor.

Sulfemi, Wahyu Bagja. (2018). Manajemen Kurikulum di Sekolah. Bogor : Visi Nusantara Maju.

Sulfemi, Wahyu Bagja. (2016). Hubungan Persepsi Peserta Didik Tentang Kompetensi Guru Mata Pelajaran Sejarah dengan Hasil Belajar Mata Pelajaran Sejarah di Kelas X SMA Negeri 1 Pamijahan Kabupaten Bogor. Fascho, 5 (2), 52-70. 